\title{
THE SARCOPHAGUS OF A NICAEAN EMPEROR IN IZMIR
}

\author{
Ergün Laflı \\ Dokuz Eylül Üniversitesi, Izmir, Turkey \\ Maurizio Buora \\ Società Friulana di Archeologia odv, Udine, Italy
}

\begin{abstract}
In this brief paper a marble slab fragment from Izmir in Western Turkey is presented. Originally its description was published by Ch. Texier in 1844 and later deemed missing. We believe that it is an imperial sarcophagus and that it may belong to the emperor of Nicaea, Theodore II Lascaris.

Key words: Imperial sarcophagus, Nymphaeum, Kemalpaşa, Izmir, Western Asia Minor, Middle Byzantine period, Late Byzantine period, Byzantine sarcophagi, Byzantine relief sculpture, Byzantine epigraphy, Byzantine history, Theodore II Lascaris, John III Ducas Vatatzes, Nicaean Empire.

Citation. Laflı E., Buora M. The Sarcophagus of a Nicaean Emperor in Izmir. Vestnik Volgogradskogo gosudarstvennogo universiteta. Seriya 4. Istoriya. Regionovedenie. Mezhdunarodnye otnosheniya [Science Journal of Volgograd State University. History. Area Studies. International Relations], 2021, vol. 26, no. 6, pp. 126135. DOI: https://doi.org/10.15688/jvolsu4.2021.6.11

УДК 902(653):726.829

ББК 63.444(5Туц)-427

Дата поступления статьи: 30.06.2021

Дата принятия статьи: 29.10.2021
\end{abstract}

\section{САРКОФАГ НИКЕЙСКОГО ИМПЕРАТОРА В ИЗМИРЕ}

\author{
Эргюн Лафлы \\ Университет Докуз Эйлюль, г. Измир, Турция \\ Маурицио Буора \\ Фриульское археологического общество, г. Удине, Италия
}

\begin{abstract}
Аннотация. В статье представлен фрагмент мраморной плиты из Измира, Западная Турция. Его описание было впервые опубликовано Ш. Тексье в 1844 г., и позже он считался утерянным. Мы полагаем, что этот фрагмент являлся частью императорского саркофага, в котором, возможно, покоились останки никейского императора Феодора II Ласкариса. Вклад авторов. Эргюн Лафлы дал подробное описание саркофага, а Маурицио Буора исследовал надпись на плите и провел ее эпиграфический анализ.

Ключевые слова: императорский саркофаг, Нимфей, Кемальпаша, Измир, Западная Малая Азия, средневизантийский период, поздневизантийский период, византийские саркофаги, византийские скульптурные рельефы, византийская эпиграфика, византийская история, Феодор II Ласкарис, Иоанн III Дука Ватац, Никейская империя.

Цитирование. Лафлы Э., Буора М. Саркофаг никейского императора в Измире // Вестник Волгоградского государственного университета. Серия 4, История. Регионоведение. Международные отношения. 2021. - Т. 26, № 6. - С. 126-135. - (На англ. яз.). - DOI: https://doi.org/10.15688/jvolsu4.2021.6.11

Introduction. On 15 October 1844 Charles Texier published in the second issue of the "Revue archéologique" a reused slab in a fountain in the

suburb of "Nymphi" (modern Kemalpaşa) $32 \mathrm{~km}$ east of Izmir (fig. 1) [28, pp. 320-325, pls. 5-8]. He gave an illustration of it and transcribed the
\end{abstract}


inscription of the upper frame (fig. 2). This slab reappeared in 2017 and is today displayed in the backyard of the Archaeological Museum of Izmir (figs. 3-4). Currently it bears no accession number.

The same author repeated the description in 1849 in the second volume of his Description de l'Asie Mineure [29, pp. 302-304] from which Adolf Kirchoff drew it for his Corpus inscriptionum graecarum [8, p. 468], in which it takes place as no. 9283 . It was later published by Henry Grégoire [9, no. 83]. In 2014 it was considered missing by Andreas Rhoby [22, p. 713]. This piece first appeared in the collection of the museum in 2017; its fragments are missing today. The measurements of the whole object are follows: length $200.0 \mathrm{~cm}$, width $65.6 \mathrm{~cm}$, thickness $9.0 \mathrm{~cm}$; letter-height $5.6 \mathrm{~cm}$, that is, two unciae. The dimensions therefore correspond to $6 \times 3$ feet, calculating the measurement of a Byzantine foot at $33.5 \mathrm{~cm}$.

As can be seen from Texier's drawing at fig. 2, it was a rectangular relief plaque with a moulding at the top and framed by architectural elements, upon which the various animal figures as well as geometric and plant ornamentations were carved in low relief: the central face as divided into figured panels on the sides (two superimposed figures separated by a band) and a central panel, with the figure of an animal at the bottom. The figurative parts were inset in rectangular frames and separated by other ornamental panels. Texier considers them as "animaux plus ou moins barbares" [29, p. 303] and interprets some images as cats ("chats") [28, p. 325].

Texier's representation and the extant piece. The comparison between the drawing published by Texier and reality of the extant piece shows some decorative differences. For example, in the rendering of the central tondo, the four flowers between the arms of the cross are in turn inserted within a semicircular cord and the corner rosettes have a very different shape. In addition, the animals of the lower left panel have legs and tails placed lower than the interwoven panels. The decoration is manifested by the intertwining of two-ply ribbons. This type of tape appears in the early $11^{\text {th }}$ century in the Byzantine world and also in Smyrna [5, fig. 27].

First panel, left. In the first pattern, at the top, there are not cats, but two lions seated facing each other, with their bushytails pointing upwards. The type recalls similar depictions, e.g. an older one in the iconostasis of the Torcello cathedral, i.e. the church of Santa Maria Assunta on the island of Torcello, Venice, for which a Costantinopolitan origin was supposed [21, pp. 116-121, nos. 75-76].

In the median range the opposite fleur-delis dividing the two representations of animals have a particular meaning. They were very popular in the Middle Byzantine period. They figure among the motifs that decorate the garments of Constantine and Justinian in the southwest vestibule mosaic with the Virgin and Child of $\mathrm{St}$ Sofia in Constantinople, made at the time of Basil II in the early tenth century. They also become a symbol of the Lascaris family and appear both in the internal decoration of the Nymphaeum palace and on their coinage. The triangular termination of the stem that is found in our slab recalls the shape of the flower that appears e.g. in a tetarteron ("quarter coin") of Theodore II Lascaris ([20, fig. 48]: type 13b, undated, for which $[11$, p. 526, pl. 36]).

In the lower panel there are two opposing birds, the one with a wide tail. Noteworthy is the series of three ribs that follow the design of the wings on the body.

Second, third and fourth panels. Panels with decorative motifs are common in several examples of Middle Byzantine sculpture in Anatolia.

The second panel features eight superimposed rows of four hollowed squares. Each row is surrounded by a smaller, equally hollow, frame.

A vertical band follows, formed by a branch and two flowers. The addition of this intermediate band means that the central part, with the cross in the tondo, is not placed exactly in the center of the face, but is slightly eccentric. A band with a plant motif is also found on the tombstone of John Comnenus Vatatzes ( $\dagger$ on 16 May 1182) preserved in the Byzantine Museum of Veroia [20, fig. 190].

The fourth panel is decorated by a series of small circles filled with rhombuses. The motif is quite common and appears on a relief in the Museum of Yalvaç, ancient Pisidian Antioch [24, fig. 4] and on other plates of the same museum, which have received an identical dating (tenth$11^{\text {th }}$ centuries) $[24$, pp. $275-276$, no. 8 , fig. 9 and pp. 279-280, no. 11, figs. 12-12a].

In the central panel there is a cross with expanded arms in the centre of the composition. Texier's drawing is not wrong, but only highlights the marginal elements and therefore does not 
allow us to grasp clearly the presence of the Greek cross. Above each arm there is a fleur-de-lis, to emphasize the union of the imperial dynasty and the Christian faith. At the corners there are four rosettes each with 12 curved and folded petals. The rendering of these rosettes by Texier is very inaccurate. The cross has a comparison with a fragment from the Museum of Yalvaç in Pisidia [24, no. 4, fig. 14].

Again, in the drawing of 1844 which is the only known image of the sarcophagus up to the present day, there is an animal in the lower part with a long tail stretched upwards.

In the extant remains we see that the front of this animal is that of a lion, whose pose and front legs are rendered in a very different way. The depiction of the lion itself indicates strength and ability to overcome opponents. The animal's attitude recalls that of other lions that appear on the edge of a marble slab from the Agora Museum of Izmir, acc. no. 119, which is dated to the seventh or eighth century A.D. [17, fig. 4]. This animal therefore presents itself well as a heraldic expression of synthesis of nobility and strength. Even in the later Palaeologan dynasty between 1253 and 1453, in their palace, Tekfur Saray1, i. e. the Palace of the Porphyrogenitus in Istanbul, there were shelves that ended in the shape of lion heads [14, p. $155 ; 20$, p. 240].

On the right, the sixth panel is perfectly identical, also in size, to the one on the other side of the panel with the cross inside the circle.

This is followed by a decoration with ribbons that cross to form right angles. Similar decoration exists in Tekfur Sarayı. In our sarcophagus the ribbons are double-headed, as is normally the case in the Byzantine world beginning from the $11^{\text {th }}$ century.

In perfect symmetry with the other end we find a panel made up of three parts: above a lion in heraldic position on the left and a fleur-de-lis on the right below. Then, below, a band with rhombuses within other rhombuses.

Finally, lower down is a pair of peacocks (?) with long necks intertwined with each other. These peacocks seem to be indicated by the crests and the body is decorated with semicircular holes, alluding to a very varied plumage. Next to each there is a fleur-de-lis. Texier reproduces the pair of animals differently and therefore the detail of the intertwined hills escapes him completely, which is a typical element of the $13^{\text {th }}$-century Byzantine art. The motif of the birds with their necks twisted together is also found in the so-called VenetianByzantine paterae of the $13^{\text {th }}$ century, which was popular in the Venetian area after the capture of Constantinople in A.D. 1204. Several are located in Venice, in the portal of the St Mark's Basilica; another with two waders (?) is located in the Campo di Santa Maria Mater Domini, Santa Croce 2173 [27], a third in the Campo dei Carmini, former Convent, Dorsoduro 2612 [26; see also 12, p. 195], and in the Fondamenta Widmann, Cannaregio 5409 [25]. They are not unknown even in the Venetian provinces, such as in the Civic Museum of Treviso, in the National Museum of Concordia, but also in the National Museum of Ravenna. In this panel it seems that each animal is juxtaposed or contrasted by a fleur-de-lis. This type of flower appears nine times on the face of the sarcophagus which has been preserved and therefore appears to reaffirm a message strongly. We believe it alludes to the imperial dignity of the deceased.

The choice of intertwining decorative motifs echoes a widespread production also in Europe from the iconoclasm period onwards. The penultimate panel with right-angled interlacing finds a comparison in one of the external decorations of the Palaeologan Tekfur Saray1.

The rendering of the frontal face, of the lions, whose body is in profile in the upper right panel recalls certain Italian pre-Romanesque sculptures of Byzantine influence, for example in the cathedral of Torcello and in other churches of the upper Adriatic area (Jader etc.).

The type of stone used. Neither the provenance of marbles used in Byzantine period in Izmir collections nor marbleworking in western Asia Minor are yet studied in detail. However, the majority of Byzantine architectural elements seem, especially Early Byzantine ones, to be products of Phrygian marble which has distinctive characteristics visible to the naked eye. But this slab from the Byzantine period does seem to be from a source of marble other than Phrygia.

To determine the marble's provenance, stable isotopic ratio analysis, petrofabric analysis, trace element analysis and electron spin resonance spectroscopy should be conducted for the Byzantine material both in the Archaeological Museum of Izmir and marbles used to construct the buildings in western Asia Minor. 
Iconography and artistic style. As said above, the peacock is a characteristic sign in funerary art [2, p. 231]. Opposing peacocks were popular on Early Byzantine sarcophagi associating the deceased with the heaven: the peacocks lived in the garden par excellence, that is Paradise, to which the deceased would arrive after death. More frequent seems to be the arrangement of peacocks on the sides of a cross, as it the case on other slabs in the Archaeological Museum of Izmir (e.g. acc. nos. 7948 and 1331).

Inscription (figs. 5-6). The inscription in a single line was already published by Texier. The complete text on the slab from Kemalpaşa which is poetical reads:

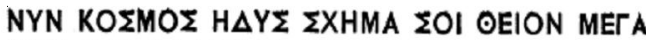

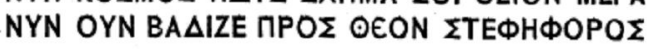

Namely:

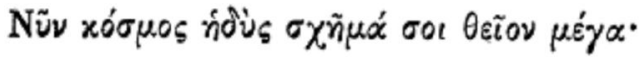

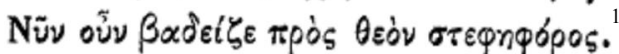

Compared to the mid- $19^{\text {th }}$ century state of conservation today some parts of the inscription are damaged, but, in any case, the text is perfectly legible. The first translation offered by Texier was criticized and corrected by an Italian archaeologist, Melchiade Fossati [16, p. 296], a young lawyer who was passionate about archaeology, made some excavations in Tarquinia [6, p. 303 and 313] and died in 1849 for the defence of the Roman Republic.

Our translation is: "Now you are dressed in a beautiful adornment, in a great and divine garment; and so now go to God with the crown on the head".

Epigraphical comments. The text, in two lines of twelve syllables each, separated by colons, is comparable to another inscription with the same characteristics in the Archaeological Museums of Istanbul, acc. no. 6144, dated by Cyril A. Mango to the $14^{\text {th }}$ century $[15$, pp. $14-15$, no. 18$]$. Twelve syllables already appear in an inscription from Ankara to exalt the victories of Michael III in the year A.D. 859 [30, p. 85].

The shape of our letters finds comparisons with another text from the same museum, acc. no. 6049 , attributed doubtfully to the $13^{\text {th }}$ century [15, pp. 9-10, no. 12]. Identical are the shapes of the mu, nu, beta and above all the alpha and delta. The form of the beta also appears in an anonymous tetarteron issued by Theodore I Lascaris [10, p. 376, pl. 69, no. 1155] which was common not only in numismatics, but also in Byzantine epigraphy and sigillography. It reappears later in the coat of arms of the Palaeologus dynasty. In our text the letter nu has two forms. The one with the wavy oblique line is identical to what appears in the church of the Forty Martyrs of Sebaste, now Şahinefendi (ancient Sobesos), to the south of Ürgüp in Cappadocia, dated to the year 1216/7 [18, p. 238]. Epsilon as well as rho have also a specific form.

For some letters, such as alpha, useful comparisons can be made with the inscription of Theodore I Lascaris on the tower 106 at Nicaea [20, fig. 19].

The term "кó $\sigma \mu \rho \varsigma$ " used here already appears in the epitaph written by Niketas Eugenianos for the poet Theodoros Prodromus in the $12^{\text {th }}$ century ("they also had your verses as a perfect adornment" [23, p. 267]).

The inscription belonged to an extensive sarcophagus, designed for a notable personality. The fact that at least in the mid- $19^{\text {th }}$ century this sarcophagus was located near the Laskarids' palace in Nymphaeum, suggests that the deceased was related to the court. This is also confirmed by the richness of the decoration. Taking the occurrence of the epithet $\sigma \tau \varepsilon \varphi \eta \varphi o ́ \rho o \varsigma$ as a basis, Grégoire argues that the first inscription was a part of an imperial sarcophagus, and adds that two Byzantine emperors were buried near Smyrna, i.e. John III Ducas Vatatzes and Theodore II Lascaris [9, no. 83]. In fact, the term $\sigma \tau \varepsilon \varphi \eta \varphi$ ó $\rho \varsigma$, already used for the winners of sports competitions ${ }^{2}$, here seems to belong to the emperors. We find it in an inscription from Ankara from the year of 859 remembering the victory of Michael III [30, p. 85]. The emperor Manuel Comnenus defined himself with this term in the cross of Notre Dame which was already owned by him [13, p. 771].

Therefore, the sarcophagus must belong to one of these dignitaries. The insistent presence of fleurs-de-lis and, perhaps, also that of the lion (symbol of imperial authority?) would seem to confirm this hypothesis.

Although Texier firmly affirms that the letters can be dated to the second half of the $13^{\text {th }}$ century, comparisons with paleography cannot be so accurate and it is perhaps not correct 
to rely on dating of the abovementioned monuments and draw conclusions about the dating of the inscription on our sarcophagus; however, letters' form is not incompatible with a dating to the $13^{\text {th }}$ century.

The deceased. The slab appears to belong to the sarcophagus of a Nicaean emperor buried in (the church?) of the monastery of Sosandra (modern Yoğurtçu Kale) in Manisa near Izmir. George Acropolites (1217 or 1220-1282) writes that when he felt death approaching, the emperor John III Ducas Vatatzes went to his beloved residence in Nymphaeum which was located few kilometers inland from the city of Smyrna [7, p. 60]: "The most prestigious monastic foundation of the Nicaean period was unquestionably the imperial monastery of Sosandra" [19, p. 665]. John III Ducas Vatatzes had founded it to accommodate his and his family's burial. Elena Asenina and Bulgaria, the wife of Theodore II Lascaris, who died perhaps in 1151 or 1152 , was probably buried here as well [3, p. 240]. In 1922 Grégoire believed that the sarcophagus had belonged to Theodore II Lascaris [9, pp. 24-25]. In his work that has appeared in 2019 Dimiter G. Angelov assumes that the sarcophagus belonged to Theodore II Lascaris, the son of John III Ducas Vatatzes, who wanted to be buried dressed as a monk. In this way he comments the inscription as a reference to the garments and also recalls that not only the emperors wore the crown, but also other dignitaries of the imperial court, e.g. despots and sebastokratores [4, p. 392].

On the other hand, in 1965 Helène Ahrweiler believed that the sarcophagus belonged to John III Ducas Vatatzes [1, p. 43].

Conclusions. "A rediscovery of the sarcophagus could perhaps shed get new light on the character of this monument" wroteAngelov [4, p. 392]. The main face of the sarcophagus from Nymphaeum has not disappeared, as many authors have written, but it is today curated in the Archaeological Museum of Izmir.
Therefore, we are now able to compare the representation offered to us by Charles Texier with reality. We are dealing with an artefact that certainly dates back to the mid- $13^{\text {th }}$ century. Our interpretation enables a fixed point for the dating of the Late Byzantine sculpture, which incorporates a diversification of tradition that already existed. We do not have enough securelyinterpreted elements to distinguish whether it is the sarcophagus of John III Ducas Vatatzes or his son Theodore II. Based on a single word of the inscription (kosmos), we take the view that the text alludes to the habit of the deceased: in the case of Theodore II, it was that of a monk. Therefore, together with other authors, we believe that our sarcophagus belongs to Theodore II Lascaris, rather than to his father, John III Ducas Vatatzes.

In any case it is a monument of extreme importance, which deserves to be known and valued. In the 2022 issue of this journal we intend to publish a second slab from the same context.

\section{ACKNOWLEDGEMENTS}

For the study of this object at the Archaeological Museum of Izmir three authorisations have been issued to E. Laflı by the Directorate of the Museum of Izmir on 11 January 2012, 18 January 2012 and 23 February 2012 and numbered as B.16.4.KTM.0.35.14.00-155.99/150, 233 and 604. Documentation was done in 2012 and all the photos were taken by E. Laflı in 2021. Fig. 1 was arranged by Dr Sami Pataci (Ardahan) in 2021 for which we would like to express Dr Pataci our gratitude.

We also would like to thank Professor Peter Liddel (Manchester) for his kind revision of our text.

\section{NOTES} $\beta \alpha ́ \delta i \zeta \varepsilon$.

${ }^{1}$ The form $\beta \alpha \delta \varepsilon i \zeta \varepsilon$ should be corrected to

${ }^{2}$ It appears already in Roman times, e.g. on a marble stele in Cyrene: Inscriptions of Roman Cyrenaica, no. C 152 . 


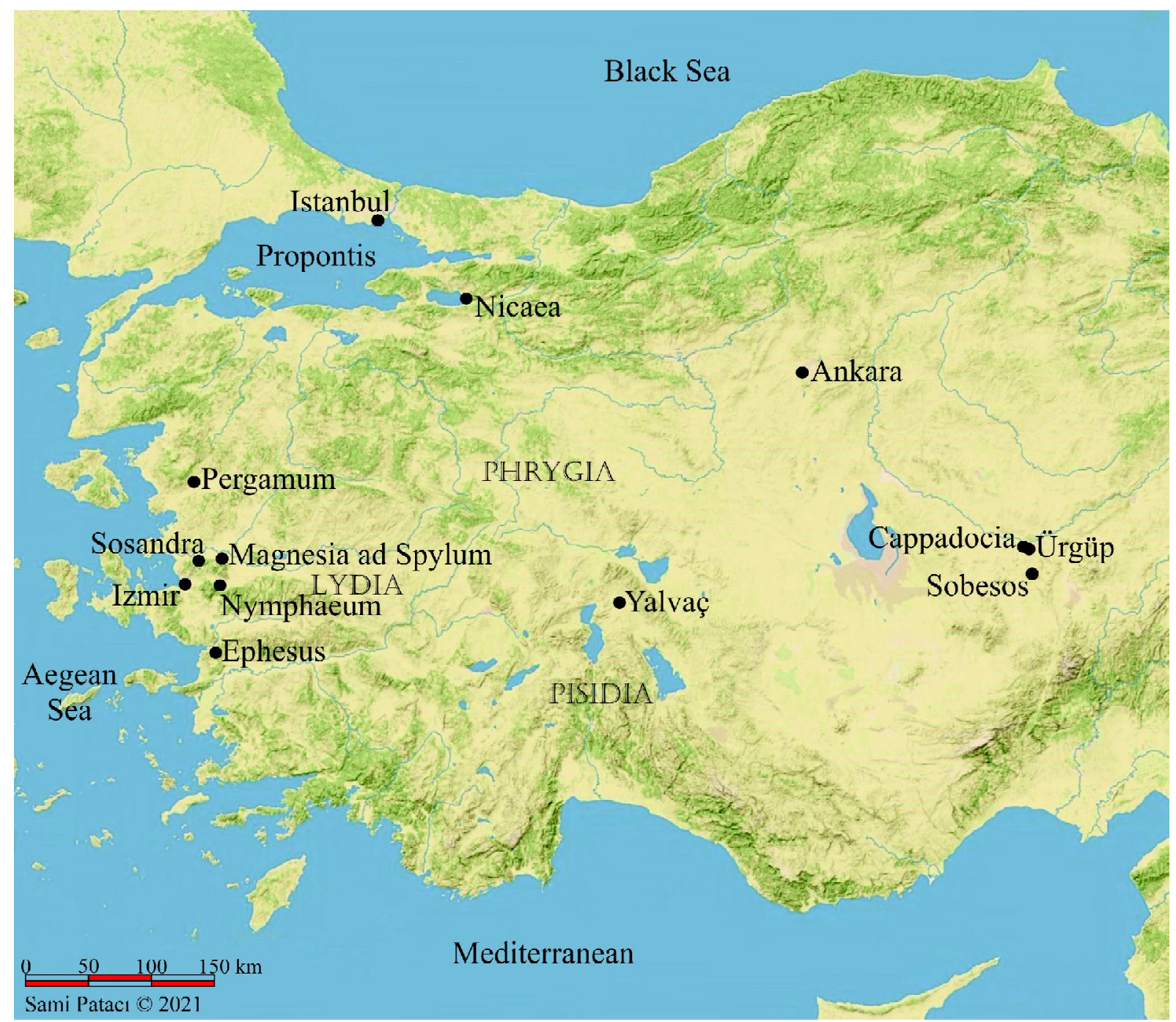

Fig. 1. Places referred to in Western Asia Minor (by S. Patac1, 2021)

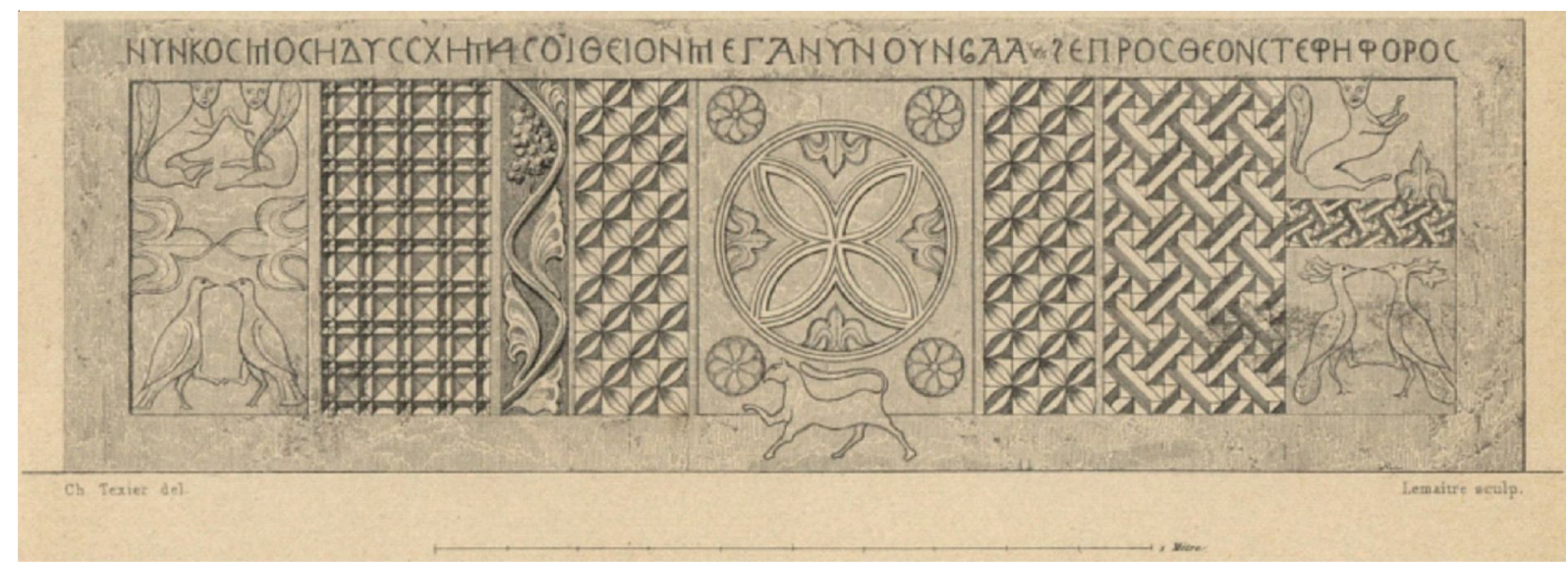

Fig. 2. Illustration of the sarcophagus of a Nicaean emperor from Kemalpaşa by Charles Texier in 1844 (after [28, pl. 7]) 


\section{ВИЗАНТИЙСКАЯ ЭПИГРАФИКА}
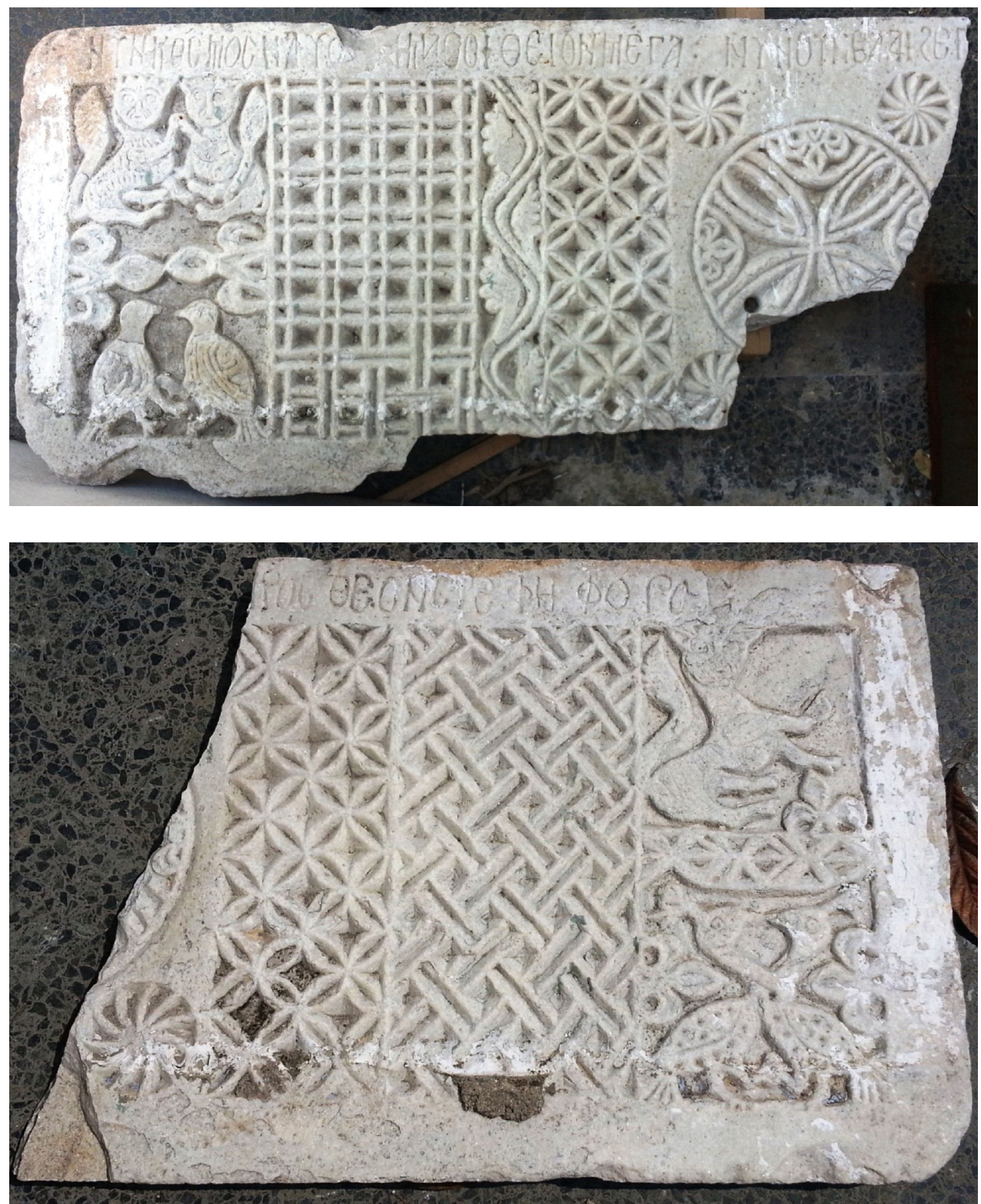

Figs. 3, $a-b$. The sarcophagus of a Nicaean emperor in the Archaeological Museum of Izmir (photo E. Lafl1, 2021) 


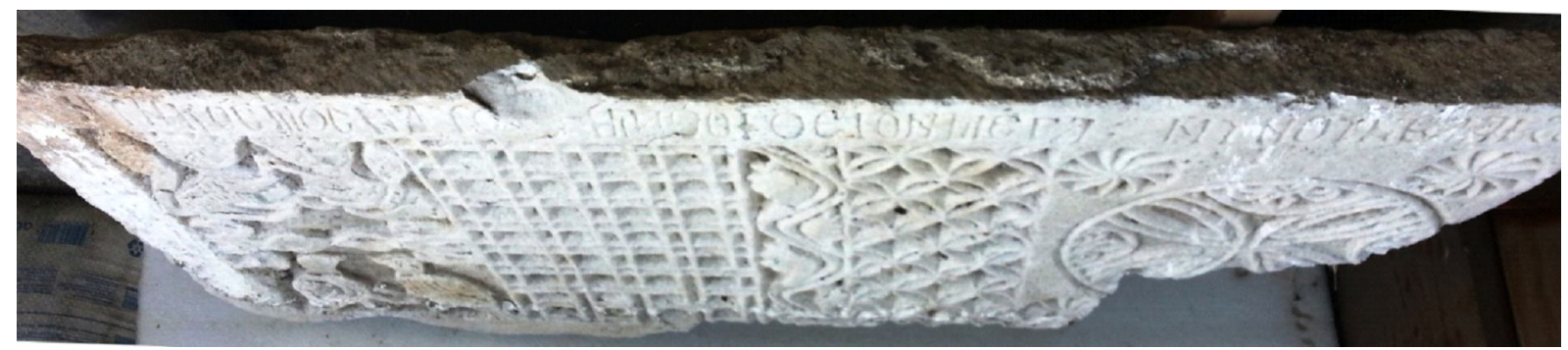

Fig. 4. Upper edge (photo E. Lafl1, 2021)
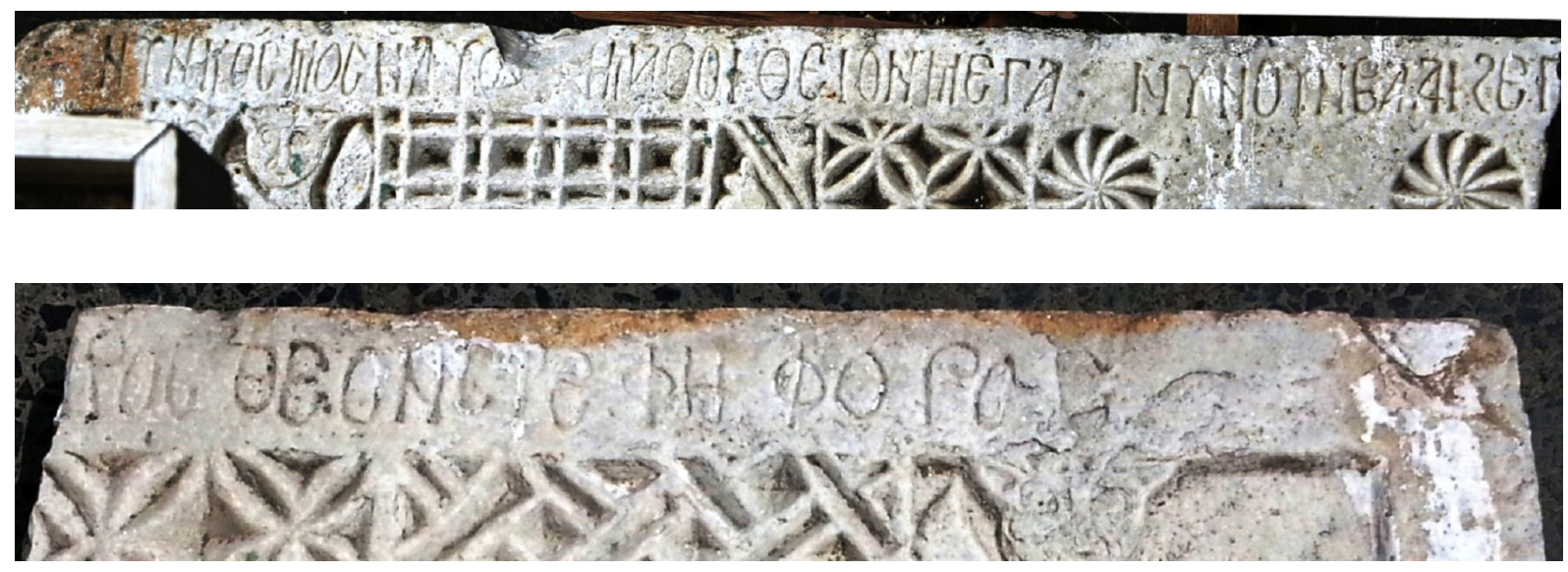

Figs. 5-6. Inscription (photo E. Lafl1, 2021) 


\section{REFERENCES}

1. Ahrweiler H. L'histoire et la géographie de la région de Smyrne entre les deux occupations turques (1081-1317), particulièrement au XIII' ${ }^{\mathrm{e}}$ siècle. Travaux et mémoires, 1965, vol. 1, pp. 1-204.

2. Anđelković J., Rogić D., Nikolić E. Peacock As a Sign in the Late Antique and Early Christian Art. Archaeology and Science, 2010 (2011), vol. 6, pp. 231-248.

3. Angelov D. The "Moral Pieces" by Theodore II Laskaris. Dumbarton Oaks Papers, 2011-2012, vol. 65/ 66, pp. 237-269.

4. Angelov D. The Byzantine Hellene: the Life of Emperor Theodore Laskaris and Byzantium in the Thirteenth Century. Cambridge, Cambridge University Press, 2019. xx, $441 \mathrm{p}$.

5. Barsanti C. La scultura mediobizantina fra tradizione e innovazione. Conca F., Fiaccadori G., eds. Bisanzio nell'età dei Macedoni. Forme della produzione letteraria e artistica. Atti dell'VIII Giornata di Studi Bizantini (Milano, 15-16 marzo 2005). Milan, Cisalpino, 2007, pp. 5-50. (Quaderni di Acme; vol. 87).

6. Bottacin A. Stendhal 'archeologo' nell'antica Etruria meridionale. La nascita di una grande passione (1831-1835). Studi francesi, 2008, vol. 155 (LII/II), pp. 286-323.

7. Ciolfi L.M. From Byzantium to the Web: The Endurance of John III Doukas Vatatzes' Legacy. Revue des études sud-est européennes, 2017, vol. 55, pp. 59-71.

8. Curtius E., KirchhoffA. Corpus inscriptionum graecarum. Pars 4. Berlin, Officina Acad., 1877. XX, 595, 167, XVII pl.

9. Grégoire H. Recueil des inscriptions grecques-chrétiennes d'Asie Mineure. Fasc. 1. Paris, E. Leroux, 1922. III, 128 p.

10. Grierson $\mathrm{Ph}$. Byzantine Coins. London, Methuen \& Co. Ltd., 1982. xiii, 411 p., 95 pl. (Library of Numismatics).

11. Hendy M.F. Catalogue of the Byzantine Coins in the Dumbarton Oaks Collection and in the Whittemore Collection. Vol. 4: Alexius I to Michael VIII, 1081-1261. Pt. 2: The Emperors of Nicea and Their Contemporaries (1204-1261). Washington, DC, Dumbarton Oaks Center for Byzantine Studies, 1999. vi, pp. 443-736, LIV pl. URL: https://archive.org/ details/docoins-4/DOCoins_4-2_WEB/page/n5/mode/ 2 up (accessed 1 October 2021).

12. Zorzi N., Berger A., Lazzarini L., eds. Itondi di Venezia e Dumbarton Oaks: arte e ideologia imperiale tra Bisanzio e Venezia = The Tondi in Venice and Dumbarton Oaks: Art and Imperial Ideology Between Byzantium and Venice. Rome, Viella, 2019. 258 p.

13. Maiorov A.V. The Emperor Manuel's Cross in Notre Dame: On Its Origin and Path. Greek, Roman, and Byzantine Studies, 2017, vol. 57, pp. 771-791. URL: https://grbs.library.duke.edu/article/viewFile/15940/ 7036 (accessed 1 October 2021).

14. Mango C.A. Byzantine Architecture. Milan, Electa Editrice; New York, Rizzoli, 1985. 215 p. (History of World Architecture).

15. Mango C., Ševčenko I. Some Recently Acquired Byzantine Inscriptions at the Istanbul Archaeological Museum. Dumbarton Oaks Papers, 1978, vol. 32, pp. 1-27.

16. Melchiade Fossati A. Sulla rivista archeologica di Parigi. Giornale arcadico di scienze, lettere e arti, 1846, vol. 107, pp. 286-306.

17. Mercangöz Z. Réflexions sur le décor sculpté byzantine d'Anatolie occidentale. Pennas Ch., Vanderheyde C., eds. La sculpture byzantine $\mathrm{VII}^{e_{-}}$ $X I I^{e}$ siècles. Actes du colloque international organisé par la $2^{e}$ Éphorie des antiquités byzantines et l'École française d'Athènes (6-8 septembre 2000). Athens, École française d'Athènes; Paris, De Boccard ÉditionDiffusion 2008, pp. 81-103. (Bulletin de correspondance hellénique, supplément; vol. 49). URL: https://www.academia.edu/36129133/ (accessed 1 October 2021).

18. Metivier S. Byzantium in Question in $13^{\text {th }}$ Century Seljuk Anatolia. Saint-Guillain G., Stathakopoulos D., eds. Liquid \& Multiple: Individuals \& Identities in the Thirteenth-Century Aegean. Paris, Association des amis du Centre d'histoire et civilisation de Byzance, 2012, pp. 235258. (Centre de Recherche d'Histoire et Civilisation de Byzance, Monographies; vol. 35).

19. Mitsiou E. The Monastery of Sosandra: A Contribution to Its History, Dedication and Localisation. Bulgaria Mediaevalis, 2011, vol. 2, pp. 665-683.

20. Pitamber N.R. Replacing Byzantium: Laskarid Urban Environments and the Landscape of Loss (1204-1261): Unpub. Doctoral Thesis. Los Angeles, CA, 2015. xxvii, 478 p. URL: https://escholarship.org/ uc/item/973684fr (accessed 1 October 2021).

21. Polacco R. Sculture paleocristiane e altomedievali di Torcello. Treviso, Marton, 1976.201 p.

22. Rhoby A. Byzantinische Epigramme in inschriftlicher Überlieferung. Vol. 3: Byzantinische Epigramme auf Stein nebst Addenda zu den Bänden 1 und 2. Vienna, Verlag der Österreichische Akademie der Wissenschaften, 2014. 1047 p. (Denkschriften der Philosophisch-Historischen Klasse Ser.; vol. 474; Veröffentlichungen zur Byzanzforschung; vol. 35). URL: http://austriaca.at/7601-5inhalt?frames=yes (accessed 1 October 2021).

23. Rhoby A. Text As Art? Byzantine Inscriptions and Their Display. Berti I., Bolle K., Opdenhoff F., Stroth F., eds. Writing Matters, Presenting and Perceiving Monumental Inscriptions in Antiquity and 
the Middle Ages. Berlin, Boston, MA, De Gruyter, 2017, pp. 265-284. (Materiale Textkulturen; vol. 14). URL: https://oi.org/10.1515/9783110534597-011.

24. Ruggieri V. La scultura bizantina nel territorio di Antiochia di Pisidia. Jahrbuch der Österreichischen Byzantinistik, 2006, vol. 56, pp. 267-296.

25. Scultura Esterna-Cannaregio 2. Venicewiki.URL: https://venicewiki.org/wiki/Scultura_Esterna_Cannaregio_2 (accessed 1 October 2021).

26. Scultura Esterna - Dorsoduro 2. Venicewiki. URL: https://venicewiki.org/wiki/Scultura_Esterna__Dorsoduro_2 (accessed 1 October 2021).

27. Scultura Esterna - Santa Croce 2. Venicewiki.URL: https://venicewiki.org/wiki/Scultura_Esterna__Santa_Croce_2(accessed 1 October 2021).
28. Texier Ch. Tombeaux du Moyen Age à Kutayah et à Nymphi (Asie Mineure). Revue archèologique, 1844, no. 2, pp. 320-325, pls. 5-8.

29. Texier Ch. Nymphaeum. Texier Ch. Description de l'Asie Mineure: faite par ordre du gouvernement français en 1833-1837; beaux-arts, monuments historiques, plans et topographie des cités antiques. Vol. 2. Paris, Firmin-Didot, 1849, pp. 302-304.

30. Mitchell S., French D., eds. The Greek and Latin Inscriptions of Ankara (Ancyra). Vol. 2: Late Roman, Byzantine and Other Texts. Munich, Verlag C.H. Beck, 2019. (Vestigia; vol. 72). URL: https:// www.beck-elibrary.de/10.17104/9783406736254/thegreek-and-latin-inscriptions-of-ankara-ancyra (accessed 1 October 2021).

\section{Information About the Authors}

Ergün Laflı, Doctor, Professor, Edebiyat Fakültesi, Arkeoloji Bölümü, Dokuz Eylül Üniversitesi, Oda No A-418, Tınaztepe/Kaynaklar Yerleşkesi, Buca, TR-35160 Izmir, Turkey, elafli@yahoo.ca, http://deu.academia.edu/ErgunLAFLI, https://orcid.org/0000-0002-4722-5018

Maurizio Buora, Doctor, Società Friulana di Archeologia odv, Via Micesio 2, Torre di Porta Villalta, I-33100 Udine, Italy, mbuora@libero.it, https://independent.academia.edu/mauriziobuora, https://orcid.org/0000-0002-5746-8312

\section{Информация об авторах}

Dr Эргюн Лафлы, профессор классической археологии, факультет литературы, кафедра археологии, Университет Докуз Эйлюль, Oda No A-418, Tinaztepe/Kaynaklar Yerleşkesi, Buca, TR-35160 г. Измир, Турция, elafli@yahoo.ca, http://deu.academia.edu/ErgunLAFLI, https://orcid.org/0000-0002-4722-5018

Dr Маурицио Буора, Фриульское археологическое общество, Via Micesio 2, Torre di Porta Villalta, I-33100 г. Удине, Италия, mbuora@libero.it, https://independent.academia.edu/mauriziobuora, https://orcid.org/0000-0002-5746-8312 